HIGHER EDUCATION IN POSTWAR BRITAIN 


\author{
Also by W. A. C. Stewart \\ QUAKERS AND EDUCATION \\ *PROGRESSIVES AND RADICALS IN ENGLISH EDUCATION, \\ 1750-1970 \\ *THE EDUCATIONAL INNOVATORS 1750-1880 \\ (with W. P. McCann) \\ *THE EDUCATIONAL INNOVATORS, 1881-1967 \\ AN INTRODUCTION TO THE SOCIOLOGY OF EDUCATION \\ (with Karl Mannheim) \\ *Also published by Macmillan
}




\section{Higher Education in Postwar Britain}

W. A. C. Stewart

formerly Vice-Chancellor

University of Keele 
Softcover reprint of the hardcover 1st edition 1989 978-0-333-36384-3

All rights reserved. No reproduction, copy or transmission of this publication may be made without written permission.

No paragraph of this publication may be reproduced, copied or transmitted save with written permission or in accordance with the provisions of the Copyright Act 1956 (as amended), or under the terms of any licence permitting limited copying issued by the Copyright Licensing Agency, 33-4 Alfred Place, London WC1E 7DP.

Any person who does any unauthorised act in relation to this publication may be liable to criminal prosecution and civil claims for damages.

First published 1989

Published by

THE MACMILLAN PRESS LTD

Houndmills, Basingstoke, Hampshire RG21 2XS

and London

Companies and representatives

throughout the world

British Library Cataloguing in Publication Data

Stewart, W. A. C., 1915-

Higher education in postwar Britain.

1. Great Britain. Higher education, 1945-1987

I. Title

378.41

ISBN 978-1-349-07066-4

ISBN 978-1-349-07064-0 (eBook)

DOI 10.1007/978-1-349-07064-0 
For EES 


\section{Contents}

Preface $\quad$ ix

Acknowledgements $\quad$ xi

Introduction xiii

Abbreviations $\quad$ xvi

Part I Higher Education before 1945

1 The Universities 3

2 The Training of Teachers $\quad 24$

3 Technical and Technological Education 29

$\begin{array}{ll}\text { Interchapter } 1 & 39\end{array}$

Part II Higher Education in the 1950s

4 The Universities, 1945-59 45

5 The Training Colleges, 1945-59 67

6 Technical and Technological Education, 1945-59 78

Interchapter $2 \quad 86$

Part III Higher Education in the 1960s

7 The Universities $\quad 95$

8 The Colleges of Education $\quad 124$

9 Technical and Technological Education 137

$\begin{array}{ll}\text { Interchapter } 3 & 142\end{array}$

Part IV Higher Education in the 1970s

11 The End of the Colleges of Education 184

12 The Rise of the Polytechnics 200

$\begin{array}{ll}\text { Interchapter } 4 & 210\end{array}$

Part V Higher Education in the 1980s

13 The Universities 223

14 The Public Sector $\quad 252$

Part VI Surveys 1945-85

15 Universities: Numbers, Money, Policies: 1945-85

Kenneth S. Davies, Paul Walker and David

Tupman 267

16 Public Sector Higher Education: 1945-85
Leonard Cantor 
viii

Contents

Epilogue

315

Notes

326

Bibliography

345

Index

352 


\section{Preface}

I do not know of any one book which gives an historic sequence of developments which have taken place in universities, colleges of education and institutions of technical education in this country particularly since 1945, which also offers some reasons for the changes and the present position, and which tries in some measure to look ahead. This is what I have attempted and in the Introduction I explain how the book has taken the form which it has. 


\section{Acknowledgements}

The undertaking began in 1980 and I acknowledge gratitude to the Social Science Research Council (as it then was) for their award, which helped to make this work possible.

The British Academy later agreed to make a Research Award available to me to help in particular with the preparation of the manuscript and this provided timely support and encouragement.

I was pleased to resume the tolerant and patient relationships with my publishers which I had come to know and value from earlier publications. I am keenly aware that I have caused the appearance of this book already to be too long delayed.

The University of Sussex awarded me an Honorary Visiting Professorial Fellowship which has provided a university base invaluable for such a project. I acknowledge in particular the interest and constructive criticism of Sir Denys Wilkinson, Dr Geoffrey Lockwood, Professor Norman Mackenzie and Professor Tony Becher and colleagues in the Education Area and elsewhere, together with the vital services of the university library. These advantages were offered in 1979-84 when Sussex like many other universities was undergoing severe financial hardship and I recognise my good fortune.

References and adaptations are acknowledged appropriately in the text. Crown copyright statistics and other official material have been acknowledged, quoted and adapted throughout the book with the permission of the Controller of HMSO.

The following persons discussed general and particular problems with me and were generous with their time. Some are acknowledged by name in the book, but others have influenced my thinking in ways which would be difficult to separate out. So too have countless conversations with present and former students, teachers and administrators in higher education and many others who are interested but have no direct involvement. To all I express my thanks while accepting that errors and misjudgments in what follows are my responsibility alone.

I have loosely grouped the names of those interviewed under the following headings: Universities University Grants Committee (UGC), Committee of Vice-Chancellors and Principals (CVCP); The maintained sector Conference of Directors of Polytechnics (CDP), Council of Local Education Authorities (CLEA), Standing Conference of Principals and Directors of Colleges and Institutes of Higher Education (SCPDCIHE), the National Advisory Body (NAB); Government and government departments The Department of Education and Science (DES); Members of Parliament and political figures; Trades unions Association of University Teachers (AUT), National Association of Teachers in Higher 
and Further Education (NATHFE), Association of Polytechnic Teachers (APT), National Union of Students (NUS, although this is not a trade union); General Society for Research into Higher Education (SRHE), Council for National Academic Awards (CNAA), Times Higher Education Supplement (THES), Clearing House for Teacher Education.

Universities: Sir Kenneth Berrill, Mr G. Cockerill, Sir Frederick Dainton (now Lord Dainton), Lord Murray, Sir Edward Parkes, Mr N. Thomas, the late Lord Wolfenden (UGC): Mr G. Caston, Mr B. Taylor and other members of the secretariat of the CVCP: Lord Ashby, Mr S. Bragg, Professor (now Sir Frederick) Crawford, Dr D. Harrison, $\mathrm{Mr}$ J. Hodgkinson, Professor M. Kogan.

Maintained Sector: Mr P. Flowerday, Mr G. Hall, Sir Norman Lindop, Dr R. Rickett (CDP): Sir Roy Harding, Mr I. Widdison (CLEA): Mr John Bevan (NAB), Mr J. Barnett, Mr N. Merritt (SCPDCIHE), Mr C. Alves, Dr K. Keohane, Mr F. Cammaerts.

Government, government departments

Department of Education and Science: Mr R. Bird, Sir James Hamilton, Mr H. Harding, Sir Antony Part, Sir Toby Weaver.

Parliamentary figures: Dr B. Donoughue (now Lord Donoughue), Dr K. Hampson MP, Mr C. Price, Mr J. Rhodes James MP, Mr P. Whitehead. Trades unions: Mr L. Sapper (AUT), Ms Janey Rees (NATHFE), Mr D. Bullar and Dr A. Pointon (APT), Mr M. Stott (NUS).

General: Professor G. Williams, Dr E. Kerr, Mr P. Scott, Miss B. Sowerbutts.

Mrs Marion Ryan has typed my manuscripts from start to finish speedily and accurately, has seen through the final typescript and has suffered my vacillations and earned my thanks many times over. So too has Mrs Jean Taylor who prepared a large part of the revised first draft of the final typescript and corrected the multiple amendments.

My wife has borne the delays and the lengthening vista of completion with the equanimity of long experience. Only she and I know how often I have called upon her patience and encouragement. 


\section{Introduction}

This book is concerned with growth and change in higher education in this country, together with the social, cultural, economic and political context in which these took place. The first three chapters which form Part I give a brief account of higher education in the universities, the training of teachers and technical preparation before 1945, with an Interchapter reviewing the main features arising out of Part I. By this means the spread of what we now see as main agencies of higher education is brought under scrutiny long before the training of teachers or technical education was thought of as part of higher education, a term which in itself did not come into common use until after the First World War, and then almost always referred to universities only. This tripartite division with an Interchapter is a pattern for most of the rest of the book.

The principal emphasis in Part I is on universities for four main reasons. First, these institutions have the longest history. Second, they have the most extensive literature. Third, they have the most international continuing network, both intellectual and institutional. One has only to recall Graeco-Roman origins, Constantinople, Alexandria, Arab/Moorish/ Islamic/Iberian and Italo/Franco/British linkages stretching from the fourth to the twelfth and thirteenth centuries and then on to today, to recognise the depth of this history and cultural continuity. Fourth, from Oxford and Cambridge through the Celtic and later the Scottish heritage in the fifteenth and sixteenth centuries and on to the nineteenth century expansion, the specifically British history of universities is merged into the mainstream of our national growth principally through Christian foundations or public benefactions.

Nevertheless, the training of teachers for work with children in basic education has an ancient history too through Christian, monastic and philanthropic tradition as have the preparation, training and supervision for vocational skills in crafts and arts through the medieval guilds and companies. Many of the implications of these issues as the centuries passed occur and recur in the text.

After presenting these broad historical perspectives to 1945 , the more chromatic and precise detailed change since then follows.

The expansion of higher education since 1945 has been extraordinary, and more persons have been involved in it and influenced by it than ever before, whether as students, teachers, in research, in administration, both in the institutions themselves and in local and national governments and 
committees, or as parents of prospective entrants, many of them first generation students, or as members of in-service training and re-education schemes. The impending period of contraction in the 1990s creates anxiety and confusion together with no less of a sense of involvement in whatever changes lie ahead.

Those involved directly in the conduct of higher education should find enough detail here to mesh with their academic, administrative or political perspectives. Those trying to unravel what happened to teacher education in the last ten years should find some answers. Those seeking to understand how the binary system came about and what it is, should find help. How do polytechnics see themselves and how, where, when and why did colleges of higher education appear? Does university autonomy exist, and what are its distinctive features? Have any guiding principles for the provision and planning of higher education emerged?

The chronological treatment seeks to ensure that the organisational changes and the politics and influences that led to them are recounted and considered.

Two chapters have been written for the book by specialist authors whose work I know well (see Part VI). Taking the general headings: numbers; money, policies, each chapter covers the whole period 1945 to the 1980 s, the first for the universities and the second for the maintained sector. They present a statistical foundation for the main structure of the system and the changes that have taken place during those forty years in continuing broad sequence and I have regarded these chapters as a deposit account on which I have been able to draw for my more detailed current account. Kenneth Davies has been for many years a senior administrator of the Committee of Vice Chancellors and Principals (CVCP) whose main responsibility has been both to undertake critical analysis of the statistics provided by other bodies like the University Grants Committee (UGC), the Department of Education and Science (DES), the Treasury and the Research Councils and to gather and present independent statistical material to the CVCP. With his former colleague at the CVCP working in this area, Paul Walker, and his present colleague David Tupman, Mr Davies has written the condensed statistical analysis which I invited him to provide.

The other author, Professor Leonard Cantor of Loughborough University of Technology, has, with Mr I. F. Roberts of the University of Keele, written acknowledged authoritative texts on the growth and development of the institutions of advanced further education which constitute the public sector. I invited Professor Cantor to write on the non-university sector under the general headings of numbers, money, policies as has been provided for the universities and he has described how 
the alternative system grew and developed since 1945, how the numbers and policies gained in coherence as money has increasingly been made available, where new discordances or needs for adjustment have shown themselves and in his survey he has included the colleges of education. Some may find it helpful to read through these two chapters at an early stage so that they can have a map of the terrain that I traverse in greater detail. 


\section{Abbreviations}

ABRC Advisory Board for the Research Councils

ACARD Advisory Council for Applied Research and Development

ACOST Advisory Council on Science and Technology

ACP Association of College Principals (applies to the Colleges of Advanced Technology 1956-61)

ACSP Advisory Council on Scientific Policy

ACSTT Advisory Committee on the Supply and Training of Teachers

AEC Association of Education Committees

AFE Advanced Further Education

AFEC Advanced Further Education Council

APR Age Participation Ratio

APT Association of Polytechnic Teachers

ARC Agricultural Research Council, (now AFRC Agricultural and Food Research Council)

AS Advanced Supplementary

ASTMS Association of Scientific Technical and Managerial Staffs

ATO Area Training Organisation

ATCDE Association of Teachers in Colleges and Departments of Education

ATTI Association of Teachers in Technical Institutions

AUBC (ACU) Association of the Universities of the British Commonwealth (later the Association of Commonwealth Universities)

AUT Association of University Teachers

BTEC Business and Technological Education Council

CAT College of Advanced Technology

CATE Council for the Acreditation of Teacher Education

CDP Committee of Directors of Polytechnics

CEAST Centre for Exploitable Areas of Science and Technology

CEI Council of Engineering Institutions

CGLI City and Guilds of London Institute

CIs Central Institutions

CLEA Council of Local Education Authorities

CNAA Council for National Academic Awards

CSP Council for Scientific Policy

CSU Civil Servants Union

CTE Council for Tertiary Education

CVCP Committee of Vice-Chancellors and Principals

DAFS Department of Agriculture and Fisheries (Scotland)

DES Department of Education and Science

DHSS Department of Health and Social Security 
Dip.HE Diploma in Higher Education

DSIR Department of Scientific and Industrial Research

ESRC Economic and Social Research Council (formerly SSRC)

FBA Fellow of the British Academy

FRS Fellow of the Royal Society

FSSU Federated Superannuation Scheme for Universities

FTEs Full-time equivalents

HE Higher Education

HMI Her Majesty's Inspector

HMSO Her Majesty's Stationery Office

HND Higher National Diploma

ILEA Inner London Education Authority

IMF International Monetary Fund

LEA Local Education Authority

MRC Medical Research Council

NAB National Advisory Board for Public Sector Higher Education

NABLAHE National Advisory Board for Local Authority Higher Education

NACEIC National Advisory Council on Education in Industry and Commerce

NACTST National Advisory Council on the Training and Supply of Teachers

NATHFE National Association of Teachers in Higher and Further Education

NCTA National Council of Technological Awards

NCTET National Council for Teacher Education and Training

NERC Natural Environment Research Council

NUS National Union of Students

OECD Organisation for European Cooperation and Development

OPEC Organisation of Petroleum Exporting Countries

OU Open University

PCFC Polytechnics and Colleges Funding Council

PESC Public Expenditure Survey Committee

PEVE Post-experience vocational education

PICKUP Professional, Industrial and Commercial Updating Programme PSHE Public Sector Higher Education

QPI Qualified participation index

RAC Regional Advisory Council

RCCDE Regional Councils for Colleges and Departments of Education

$R$ and D Research and Development

SCDC Secondary Curriculum Development Council

SCDPCIHE Standing Conference of Directors and Principals of Colleges and Institutes of Higher Education

SCOTVEC Scottish Vocational Education Council 
SCOVACT Scottish Council for the Validation of Courses for Teachers SCUE Standing Conference on University Entrance

SEC Secondary Examinations Council

SED Scottish Education Department

SERC Science and Engineering Research Council (formerly SRC)

SHEPC Scottish Higher Education Planning Council

SHEPFC Scottish Higher Education Planning and Funding Council

SISTER Special Institutes for Scientific and Technological Education and Research

SIT Scottish Institute of Technology

SRC Science Research Council (now SERC)

SSRC Social Science Research Council (now ESRC)

STEAC Scottish Tertiary Education Advisory Council

TEC Technical Education Council

THES Times Higher Education Supplement

TUC Trades Union Congress

TVEI Technical Vocational Education Initiative

UCB University College, Buckingham

UCCA Universities Central Council on Admissions

UCNS Universities Council for Non-Teaching Staff

UFC Universities Funding Council

UGC University Grants Committee

USR University Statistical Record

USS University Superannuation Scheme

VSCC Voluntary Sector Consultative Committee

WAB Welsh Advisory Board

YTS Youth Training Scheme 